\title{
Preparation of Cell Lysate for Separation of Polyoma DNA from Cellular DNA by Sedimentation Velocity*
}

\author{
Kentaro Toh, Tomizo Okuyama, Masakatsu Imamura \\ and KoKICHI KIKUCHI \\ Department of Pathology, Sapporo Medical College, Sapporo
}

\begin{abstract}
Toh, K., Okuyama, T., Imamura, M. and Kikuchi, K. Preparation of Cell Lysate for Separation of Polyoma DNA from Cellular DNA by Sedimentation Velocity. Tohoku J. exp. Med., 1973, 111 (4), 347-351 — A simple procedure was devised to prepare the cell lysate for clear separation of viral and cellular DNA by sedimentation velocity allowing simultaneous observation of changes of both DNAs. This method was also useful to detect grades of fragmentation of DNA due to treatment of cells with drugs or to physical influences. —_ polyoma virus; DNA; sedimentation velocity centrifugation
\end{abstract}

Clear separation of viral DNA from cellular DNA in virus infected cells is required for the study of dynamics of viral infection, especially for the study of relationships between metabolisms of viral and host DNAs. Several separation procedures have been devised (Dulbecco et al. 1965; Weil et al. 1965), but they are still partial or incomplete. The difficulty is due mainly to the fact that DNA of the mammalian cell is apt to degrade easily during the course of extraction, producing DNA fragments of similar size to viral DNA. Hirt (1967) succeeded in extracting polyoma virus DNA selectively from infected cell cultures, but no particular concern was paid to cellular DNA.

In the present study, we modified Hirt's method and devised a simple procedure to prepare the cell lysate for clear separation of viral and cellular DNAs by sedimentation velocity allowing simultaneous observation of both DNAs.

\section{Materials and Methods}

The cell lysates were prepared as follows. Both normal and polyoma infected cell cultures, which were labelled with radioactive isotopes as described in the legends to the figures, were dispersed by means of a $0.1 \%$ trypsin solution containing $0.1 \%$ EDTA using rubber policeman, and pelled by low speed centrifugation. The supernatant was discarded and the cells were suspended in Tris buffer saline $(0.02 \mathrm{M}$ Tris- $\mathrm{HCl}, \mathrm{pH} 7.5$, containing $0.01 \mathrm{M}$ EDTA and $0.15 \mathrm{M} \mathrm{NaCl}$ ) at an approximate strength of $2 \times 10^{8}$ cells $/ \mathrm{ml}$. Two $\mathrm{ml}$ of the cell suspension were lysed by adding $0.5 \mathrm{ml}$ of $2.5 \%$ sodium dodecylsulfate (SDS). After the lysate sat at room temperature for $10 \mathrm{~min}, 0.5 \mathrm{ml}$ of water saturated with sodium perchlorate $\left(\mathrm{NaClO}_{4} \mathrm{H}_{2} \mathrm{O}\right)$ was added to $2.5 \mathrm{ml}$ of the cell lysate. The whole cell lysate was poured into a dialysis tube with a wide mouth pipette and mixed slowly by inverting the tube. The tube was dialysed for 1 to 2 days with large volumes of Tris buffer saline

Received for publication, April 19, 1973.

* This work was supported in part by Grants-in Aid for Scientific Research from the Ministry of Education of Japan, No. 787025. 
to remove SDS and sodium perchlorate at room temperature. $0.1 \mathrm{ml}$ of this dialysed cell lysate was examined using $\mathrm{CsCl}$ band centrifugation for $3.5 \mathrm{hr}$ at $35,000 \mathrm{rpm}$ at $20^{\circ} \mathrm{C}$ in a Hitachi RPS-65 TA rotor. The $\mathrm{CsCl}$ band centrifugation was performed according to Dulbecco's description (1963), except that the density of $\mathrm{CsCl}$ solution was $1.55 \mathrm{~g} / \mathrm{ml}$ in $0.01 \mathrm{M}$ Tris-HCl, $\mathrm{pH}$ 7.5. After centrifugation, the tube was punctured at the bottom and fractions were collected on Whatman No. 3 filter paper discs. The filter papers were washed with cold $5 \%$ TCA and dried, and the radioactivity was counted with $10 \mathrm{ml}$ of toluene scincillation fluid (4.0 g PPO and $0.1 \mathrm{~g}$ POPOP/liter of toluene).

\section{Results AND Discussion}

When cell lysates prepared from polyoma infected cells were examined using $\mathrm{CsCl}$ band centrifugation, they showed fast- and slow-sedimenting DNA peaks that were well separated from each other (Fig. 1a). Both DNA peaks were free of protein as evidenced by the absence of counts of ${ }^{14} \mathrm{C}$ in the fraction corresponding to the DNA peaks when the cells were labelled with a mixture of ${ }^{14} \mathrm{C}$-leucine and ${ }^{14} \mathrm{C}$-lysine with ${ }^{3} \mathrm{H}$-thymidine in the same culture. When the cell lysates were mixed with ${ }^{14} \mathrm{C}$-labelled polyoma DNA, which was prepared with Hirt's procedure (Hirt 1967), and sedimented through a $\mathrm{CsCl}$ solution, ${ }^{14} \mathrm{C}$-labelled polyoma DNA showed the same sedimentation velocity as the slow-sedimenting ${ }^{3} \mathrm{H}$-labelled

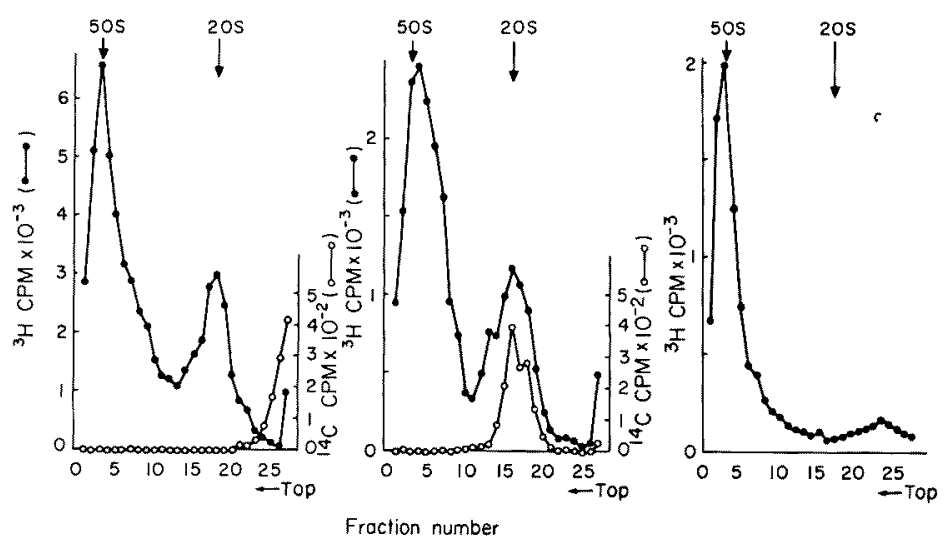

Fig. 1. $\mathrm{CsCl}$ band centrifugation of cell lysate prepared from normal and polyoma infected mouse kidney cell eultures.

(a) Confluent mouse kidney cell cultures were infected with polyoma virus (m.o.i. 100) and incubated in Eagle's MEM without serum. The cells were labelled with 5.0 $\mu \mathrm{Ci} / \mathrm{ml}$ of ${ }^{3} \mathrm{H}$-thymidine and $0.5 \mu \mathrm{Ci} / \mathrm{ml}$ each of ${ }^{14} \mathrm{C}$-leucine and ${ }^{14} \mathrm{C}$-lysine in Eagle's MEM lacking leucine and lysine from 24 to $27 \mathrm{hr}$ after infection. The cell lysate was prepared and examined by $\mathrm{CsCl}$ band centrifugation as described, in text.

(b) Polyoma-infected mouse kidney cell cultures were labelled with $2.0 \mu \mathrm{Ci}$ of ${ }^{3} \mathrm{H}$ thymidine per $\mathrm{ml}$ from 21 to $24 \mathrm{hr}$ after infection and the cell lysate was prepared as described in text. A mixture of this cell lysate and ${ }^{14} \mathrm{C}$-labelled polyoma DNA prepared with Hirt's procedures was examined by $\mathrm{CsCl}$ band centrifugation.

(c) Mouse kidney cells were grown in the presence of $2.0 \mu \mathrm{Ci} / \mathrm{ml}{ }^{3} \mathrm{H}$-thymidine in Eagle's MEM supplemented with 10\% Tryptose phosphate broth and $10 \%$ calf serum from 24 to $72 \mathrm{hr}$ after seeding. The cell lysate was prepared and examined by $\mathrm{CsCl}$ band centrifugation as described in text. 
DNA (Fig. 1b). The cell lysate from a normal mouse kidney culture grown in the presence of ${ }^{3} \mathrm{H}$-thymidine did not contain the slow sedimenting DNA, but contained the same fast-sedimenting DNA as observed in polyoma infected cells (Fig. 1c).

From the above results, it can be assumed that the slow- and fast-sedimenting DNAs observed in polyoma infected cells are polyoma DNA and cellular DNA, respectively.

Confluent mouse kidney cell cultures were infected with polyoma virus and pulse-labelled with ${ }^{3} \mathrm{H}$-thymidine at a number of different times after infection. Fig. 2 clearly shows that the peak of polyoma DNA increased in beight in direct proportion to the time after infection. This peak was never observed in mock infected cells. Induction of cellular DNA synthesis by polyoma infection (Dulbecco et al. 1965; Weil et al. 1965) was clearly shown to result in increase of fast-sedimenting DNA by this method (Fig. 2).

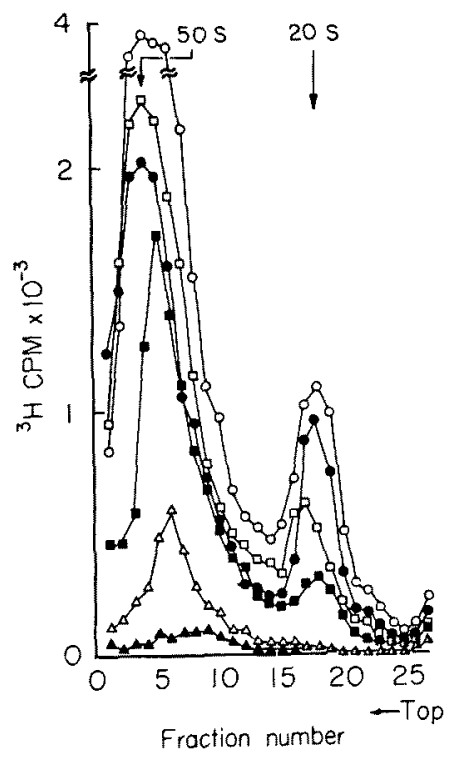

Fig. 2. $\mathrm{CsCl}$ band centrifugation of cell lysate prepared from pulse-labelled cells at different times after polyoma infection. Polyoma-infected mouse kidney cells were pulselabelled with $2.0 \mu \mathrm{Ci}$ of ${ }^{3} \mathrm{H}$-thymidine per $\mathrm{ml}$ for $3 \mathrm{hr}$ at different times after infection. Cell lysate were prepared from each pulse-labelled mouse kidney cell culture as mentioned in text and were examined using $\mathrm{CsCl}$ band centrifugation. (A- 1 ) $-3-0 \mathrm{hr}$;

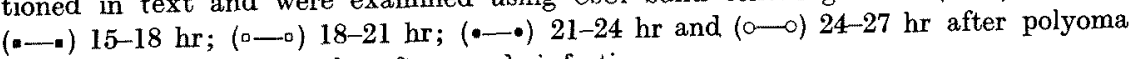

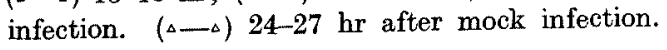

Cell lysate prepared in the manner as described in Fig. 1b was shaken by hand in the presence of chloroform-isoamylalcohol and the influence of shaking on sedimentation velocity of DNA was examined. As shown in Fig. 3, even a 5-second shaking of the cell lysate caused the shift of the peak of cellular DNA to a slowersedimenting fraction. As the time of shaking was prolonged, the peak of cel- 
lular DNA gradually shifted to slower-sedimenting fractions and after 120 seconds of shaking, the location of the peak of cellular DNA was close to that of the fraction of polyoma DNA. On the contrary, polyoma DNA remained almost unchanged even after shaking. These results show that cellular DNA is easily degraded mechanically by shaking and this had made it difficult to separate viral DNA from cellular DNA by sedimentation velocity. Fragmentation of DNA in cells treated with Mitomycin $\mathrm{C}$ or Actinomycin $\mathrm{D}$ was also clearly observed by this method (data not shown).

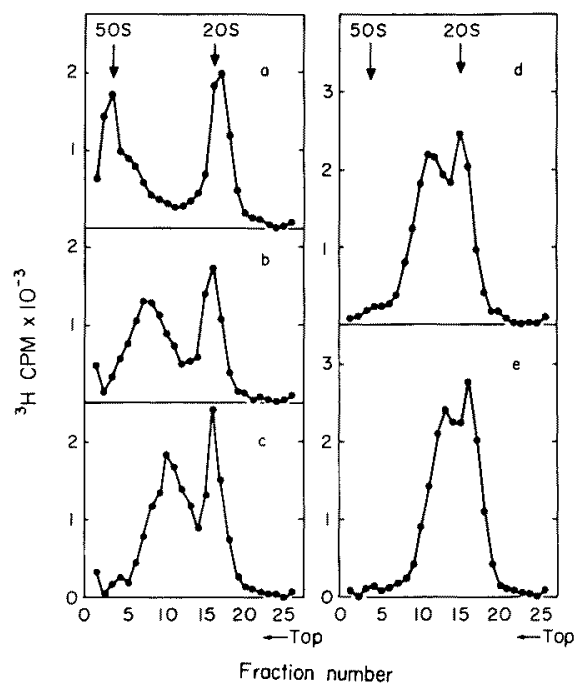

Fig. 3. Influence of shaking on sedimentation velocity of DNA. Cell lysate was prepared from polyoma infected mouse kidney cells. Three $\mathrm{ml}$ of this cell lysate was taken into a 10-ml glass centrifuge tube and shaken by hand (20 times per 5 seconds) in the presence of an equal volume of chloroform-isoamylalcohol (24:1). After shaking, the tube was centrifuged for $5 \mathrm{~min}$ at $3,000 \mathrm{rpm}$ and $0.1 \mathrm{ml}$ of aqueous solution was examined by $\mathrm{CsCl}$ band centrifugation. Shaking was performed for 0 sec (a), 5 sec (b), $20 \sec (\mathrm{c}), 60 \mathrm{sec}(\mathrm{d})$, and $120 \mathrm{sec}(\mathrm{e})$.

When the cell lysate was stored at $4^{\circ} \mathrm{C}$, the sedimentation pattern of DNA was preserved at least for 4 weeks.

The procedure described in this paper enables us easily to prepare DNA samples for separating viral and cellular DNAs in polyoma infected cells, and the results with sedimentation velocity centrifugation are reproducible. The methods are useful not only to separate viral and cellular DNAs in the virus-infected cells, but also to detect fragmentation of nuclear DNA due to treatment of cells with drugs or to physical influences.

\section{References}

1) Dulbecco, R., Hartwell, L.H. \& Vogt, M. (1965) Induction of cellular DNA synthesis by polyoma virus. Proc. nat. Acad. Sci., 53, 403-410. 
2) Dulbecco, R. \& Vogt, M. (1963) Evidence for a ring structure of polyoma virus DNA. Proc. nat. Acad. Sci., 50, 236-243.

3) Hirt, B. (1967) Selective extraction of polyoma DNA from infected mouse cell cultures. J. molec. Biol., 26, 365-369.

4) Weil, R., Michel, M.R. \& Ruschmann, G.K. (1965) Induction of cellular DNA synthesis by polyoma virus. Proc. nat. Acad. Sci., 53, 1468-1475. 